\title{
HYDROGRAPHIC AND HYDROGEOLOGICAL BASIN OF ENTRE-RIBEIROS: PROBABLE RECHARGE ZONE DELIMITATION AND ENVIRONMENTAL IMPACT ASSESSMENT
}

\section{VITOR V. VASCONCELOS ${ }^{1}$, PAULO P. MARTINS JUNIOR ${ }^{2}$, RENATO M. HADAD ${ }^{3}$}

ABSTRACT: The probable recharge zone delimitation of Entre-Ribeiros Basin (Northwest of the state of Minas Gerais / Brazil) is proposed in this study. The delimitation is based upon stratigraphy, geomorphology, geo-environmental domains and hydrogeology studies. Combining the recharge zone map with the land use variation between 1975 and 2008, the occupation trends of possible recharge zones are identified. Concluding, the environmental impacts for this basin are discussed.

KEYWORDS: hydrogeology, aquifer recharge, land use zoning, environment, soil compaction.

\section{BACIA HIDROGRÁFICA E HIDROGEOLÓGICA DE ENTRE-RIBEIROS: ZONAS PROVÁVEIS DE RECARGA E ANÁLISE DOS IMPACTOS AMBIENTAIS HISTÓRICOS}

RESUMO: Apresenta-se uma proposta de delimitação das prováveis zonas de recarga da Bacia Hidrográfica de Entre-Ribeiros (Noroeste de Minas Gerais/Brasil). A delimitação teve como subsídio estudos de litoestratigrafia, geomorfologia, unidades geoambientais e hidrogeologia. A partir da delimitação proposta, e conjugando-se à análise da ocupação do solo entre o período de 1975 a 2008, procura-se identificar as tendências de ocupação das zonas prováveis de recarga. Por fim, tecem-se comentários sobre os impactos ambientais decorrentes da ocupação dessas áreas.

PALAVRAS-CHAVE: hidrogeologia, recarga de aquíferos, zoneamento de uso do solo, meio ambiente, compactação do solo.

\section{INTRODUCTION}

The Entre-Ribeiros Basin is located in Paracatu River Basin in the Northwest of Minas Gerais, state of São Paulo, Brazil (Figure 1), between the municipalities of Paracatu and Unaí. It is a striking scenario to examine the potential effect of new agricultural fronts.

Since the year 1970, it is observed that in this basin the progressive establishment of a large irrigation system (RODRÍGUEZ et al., 2007; RODRIGUEZ, 2008), involving several farmers in an associated form. It is characterized by an agriculture which uses the latest technology, including the frequent use of circular irrigation pivots.

With the expansion of irrigated agricultural front, the use of water resources of Entre-Ribeiros reached a critical level, far below the outflow necessary for the maintenance of associated aquatic and terrestrial ecosystems (VASCONCELOS, 2009; VASCONCELOS, 2010). In periods of increased drought, there were also the conflicts between farmers for scarce water resources (PRUSKI et al., 2007, VASCONCELOS et al., 2008).

\footnotetext{
${ }^{1}$ Doutorando em Geologia, Universidade Federal de Ouro Preto, Mestre em Geografia, Especialista em Solos e Meio Ambiente, Bacharel em Filosofia, Técnico em Meio Ambiente, Técnico em Informática, vitor.vasconcelos@almg.gov.br.

${ }^{2}$ Universidade Federal de Ouro Preto (Professor), Fundação Centro Tecnológico de Minas Gerais - CETEC-MG (Pesquisador Pleno), Geólogo, Doutor em Ciências da Terra, paulo.martins@ cetec.br.

${ }^{3}$ PUC-MG (Pró-Reitor), Programa de Pós-Graduação em Geografia - Tratamento da Informação Espacial (Professor), Fundação Centro Tecnológico de Minas Gerais, CETEC-MG (Pesquisador Pleno), Doutor em Ciência da Computação, Mestre em Ciência da Computação, Bacharel em Engenharia Mecânica, rhadad@pucminas.br.

Recebido pelo Conselho Editorial em: 25-2-2011

Aprovado pelo Conselho Editorial em: 9-1-2012
} 

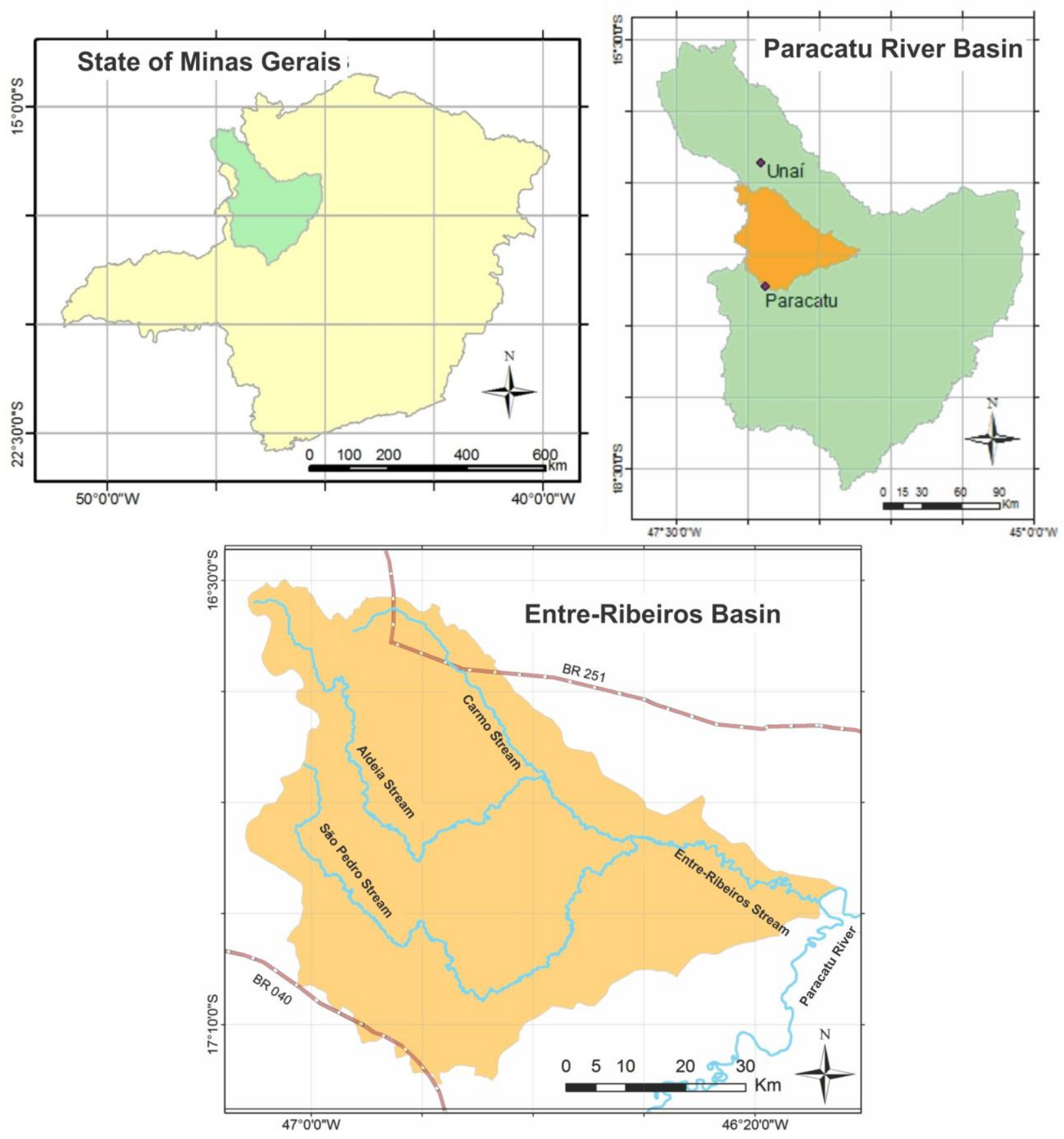

FIGURE 1. Location of Entre-Ribeiros Basin: (a) in the State of Minas Gerais, (b) in the River Paracatu Basin and (c) Sub-Basin of Entre-Ribeiros. Entre-Ribeiros in Paracatu River Basin, on the state of Minas Gerais.

\section{Investigation of recharge areas}

Through the Barnes graphic method, the Foundation Technological Center of Minas Gerais CETEC-MG (1981) estimated that, for the Paracatu River Basin at different points, there is a contribution of $32 \%$ to $48 \%$ of underground aquifers for maintaining the flow of water courses. This contribution increases as the flow presents more water recharge areas of Cretaceous sandstones and sediments of Tertiary-Quaternary cover - observation that founds the choice of these areas for the delimitation of the recharge zones of Entre-Ribeiros. However, these calculations found that the contribution and infiltration from the fractured and karst formations of the aquifer Bambuí would be very low or almost zero, compared to above granular aquifers. RAMOS \& PAIXÃO (2004) also highlight the importance of porous sedimentary aquifers for the perennial rivers of the São Francisco Basin. 
The geological units of Areado Formation (Cretaceous) are characterized by free aquifers that provide significant amounts of water through sources of slope (FUNDAÇÃO CENTRO TECNOLÓGICO DE MINAS GERAIS, 1981). They are formed by thick sandstones (up to 140 meters) and rest directly on the substrate impervious of Bambuí Group (Eocambrian Period) (FUNDAÇÃO CENTRO TECNOLÓGICO DE MINAS GERAIS, 1981). However, the underlying mesofractures identified in the Bambuí formation may increase the complexity of these aquifers through the combination between granular aquifers and fractured aquifers (MARTINS JR. et al., 2006).

Morphologically, the porous aquifers of tertiary-quaternary coverage rely upon part of the Residual Plateaus of São Francisco, forming tabular surfaces in units above 900m (ANDRADE, 2007). In the case of Entre-Ribeiros Basin, it is tabular surfaces slightly reworked, with virtually no drainage, which features a thick sedimentary layer with high capacity of potential infiltration (FUNDAÇÃO CENTRO TECNOLÓGICO DE MINAS GERAIS, 1981). These aquifers have an average thickness of $10 \mathrm{~m}$, although exceptionally reach 30 meters (RURALMINAS, 1996), with registration of up to 80 meters (MOURÃO, 2001).

The main discharge areas are located at the base of the elevations, along the edge or rim of the plateaus (Figure 2), in the contact between the sandstone and the impervious substrate. The surface of the water table aquifer follows a strong topographic control with flow lines converging toward the main drains, indicating that the main water courses have character effluent, or receive contributions of groundwater (FUNDAÇÃO CENTRO TECNOLÓGICO DE MINAS GERAIS, 1981).

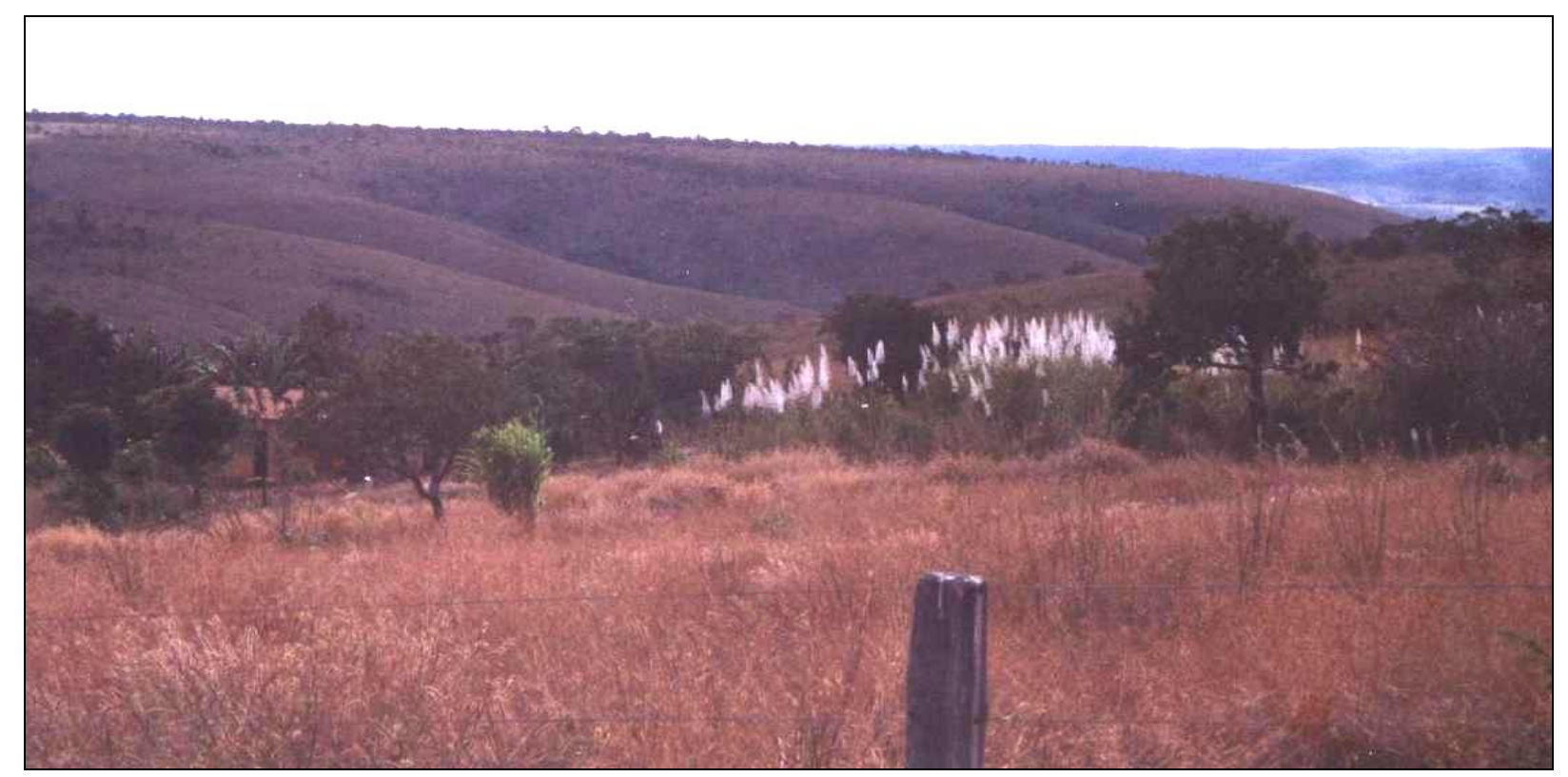

FIGURE 2. Discharge Areas of aquifers at high tabular zones, in Entre-Ribeiros Basin. XV Settlement Project of November. Source: FEDERAL UNIVERSITY OF VIÇOSA / FUNARBE (2006)

The latest Tertiary-Quaternary sedimentary aquifers, which are located in regions of the lowland plains of the River Paracatu Basin, cover the low permeability pelites of the Bambuí Group; there is often the exudation in the area of contact between these two sediment mass (FUNDAÇÃO CENTRO TECNOLÓGICO DE MINAS GERAIS, 1981; MOURÃO, 2001). For the predominant landforms of the planning surfaces for this sediment mass (ANDRADE, 2007), one can hypothesize the existence of flows of local and regional basis, where there is a hydraulic connection between these aquifers and rivers - thus, the aquifers act as regulators of the flow of these watercourses (FUNDAÇÃO CENTRO TECNOLÓGICO DE MINAS GERAIS, 1981). Their potential for water storage is less than in other porous aquifers of the basin, due to the thinness - an 
average of 5 meters (RURALMINAS, 1996), except in depressions (up to 100 meters) (MOURÃO, 2001).

In some flat areas of oxisol present on the tertiary-quaternary sedimentary aquifer, as well as all the floodplain of the medium-low Paracatu, there are areas with high density of lagoons and temporary wetlands (INSTITUTO MINEIRO DE GESTÃO DAS ÁGUAS - IGAM, 2006). According to MULHOLLAND (2009), some of these water bodies are due to outcrops of the water table aquifer, and others are due to the contribution of flooding in basins and shallow depressions on relatively impermeable shale formations.

Despite the strong water loss by evaporation - which confirms the intermittent nature of these water bodies (FUNDAÇÃO CENTRO TECNOLÓGICO DE MINAS GERAIS, 1981), these wetlands slowly contribute to the subsurface flows. In cases where there is direct connection to the water table aquifer, however, these wetlands may show the discharge areas of aquifers.

The cracked sediment masses correspond specially to the Bambuí and Canastra groups with the Paracatu, Vazante and Paranoá Formations. They are characterized by having permeability of cracks and joints. The capability of these rocks for storage and water circulation depends on the length, continuity and interconnection of the fractures, as well as the opening or void volume within these structures. The possibilities of direct infiltration of water in these storage-rocks from the pluvial water are reduced, since the discontinuities of fractures are relatively localized features (MOURÃO, 2001). The recharge takes place by vertical infiltration downwards through the upper water table or by deeper infiltration of the Cretaceous and Tertiary-Quaternary sedimentary capping, as well as the points of fracture-draining coincidence, that is, through the beds of water bodies controlled by fracture directions (RURALMINAS, 1996).

The karst aquifers of the Paracatu Basin correspond predominantly to geomorphological areas of embedded ridges and declivity (ANDRADE, 2007) of steep slopes. As they are distributed through the Deformation Zone, under strong tectonism (thrust faults, transcurrent faults and folding structures), it may assume a high degree of fracturing. Moreover, the presence of sinkholes, caves and sink indicates an endocarstic development activated by dissolution. As a result, it is assumed that such aquifers may allow a significant hydrogeological flow. However, depending on the expressiveness of the flowage in inherent ducts of the evolved karst forms, their aquifers would show a more pronounced recession coefficient, exhausting itself by providing faster and therefore less water to the springs during the high dry season.

The aquifers of the quaternary alluvial deposits are found widely along the drainage system, on flood plains and terraces. They are areas of active water exchange, receiving recharge from rivers in the rainy season, with refunds during the dry season (MOUR ÃO, 2001).

In areas of lithostratigraphic transition of the Entre-Ribeiros Basin, dominated by geomorphological features of hills and slopes, the hydrogeological role of transport areas is assumed (MARTINS JR. et al., 2006). However, some regions may have areas of discharge, due to regional tectonic structures or due to weathering mantles locally more permeable than the deeper horizons (FUNDAÇÃO CENTRO TECNOLÓGICO DE MINAS GERAIS, 1981). Nevertheless, it is worth remembering that every surface with weathered mantle contributes in part to the recharge of groundwater aquifers.

\section{Objectives}

Anchored in existing knowledge about the underground and surface aquifers of the EntreRibeiros Basin, this study aims to:

- Study the spatial variability on the favorability of recharge in the basin;

- Develop a map of probable recharge zone of Entre-Ribeiros;

- Analyze the change of land use and land cover areas of recharge; 
- Present tables of variation of the agrieconomics systems on probable recharge zone, and

- Discourse about the environmental impacts of the occupation of the hydrographic and hydrogeological basin on study.

\section{Method for delimitation and analysis of occupation of aquifer and wetlands recharge areas}

The overall operation of hydrogeological systems and key recharge areas in the Vale do São Francisco and the Northwest of Minas Gerais are presented in the studies of Planoroeste II (FUNDAÇÃO CENTRO TECNOLÓGICO DE MINAS GERAIS, 1981), and in Ramos and Paixão (2004). The most regionalized study of zones of recharge of Paracatu Basin was conducted by RURALMINAS (1996) and MARTINS JR. (2009). These studies were important to indicate which geoenvironmental units (combining lithostratigraphy, geomorphology, pedology and precipitation) may be more important for recharge of the aquifers of Entre-Ribeiros.

The limit of the recharge area for the Entre-Ribeiros Basin (hydrogeological watershed) does not always coincide with the topographic watershed (MARTINS JR., 2009), in a classic case of asymmetry between the boundaries of hydrographic and hydrogeological basins (ARRAES, 2008). However, although there are ongoing studies, it was not possible yet to trace the limits of the recharge area. For this reason, it was chosen, in this study, to adopt the boundary of the basin as a limit to the aquifers area - even aware of the inaccuracy resulting from this simplification.

The delineation of recharge areas corresponding to the geo-environmental high tabular zones covering the cretaceous sandstones - was taken from the digital bases of ANDRADE (2007), in detailed scale of 1:250,000.

The indication of recharge areas corresponding to the tertiary-quaternary granular aquifer is bounded in RURALMINAS (1996), in detailed scale of 1:500,000. However, with the digitization of lithostratigraphy and geomorphology of the region by MARTINS JR. et al. (2006), from the foundations of Planoroeste II (FUNDAÇÃO CENTRO TECNOLÓGICO DE MINAS GERAIS, 1981), made possible a new delineation of the recharge area with more precision in the EntreRibeiros Basin, adjusted to detail scale of 1:250,000.

The hydrogeological studies could be compared with the process of occupation of land use, reaching conclusions about the relationship between agriculture (economic bias) and water (ecological bias). The same method of comparison between the changes of land use in the Basin has been reproduced for the specific area defined as Probable Recharge Zones.

Studies of change in land use in 1975 and 2008 took by basilar reference the observations on the vegetation in the study conducted by FUNDAÇÃO CENTRO TECNOLÓGICO DE MINAS GERAIS (1989), contrasting with the changes of land use by the development of agricultural systems observed in images of 1 and 5 satellite Landsat of each period. Additionally, vegetation and land use maps were also taken as references, which were carried out by ASSAD et al. (1992), UNIVERSIDADE FEDERAL DE VIÇOSA/FUNARBE (2006), ANDRADE (2007), LATUF (2007) and LATUF et al. (2007).

The process can be observed in Figure 3. The diagram shows the methodological steps relating to the delimitation and analysis of occupation of areas of groundwater recharge of the Entre-Ribeiros Basin, and also presents the main information bases to carry out the activities. 


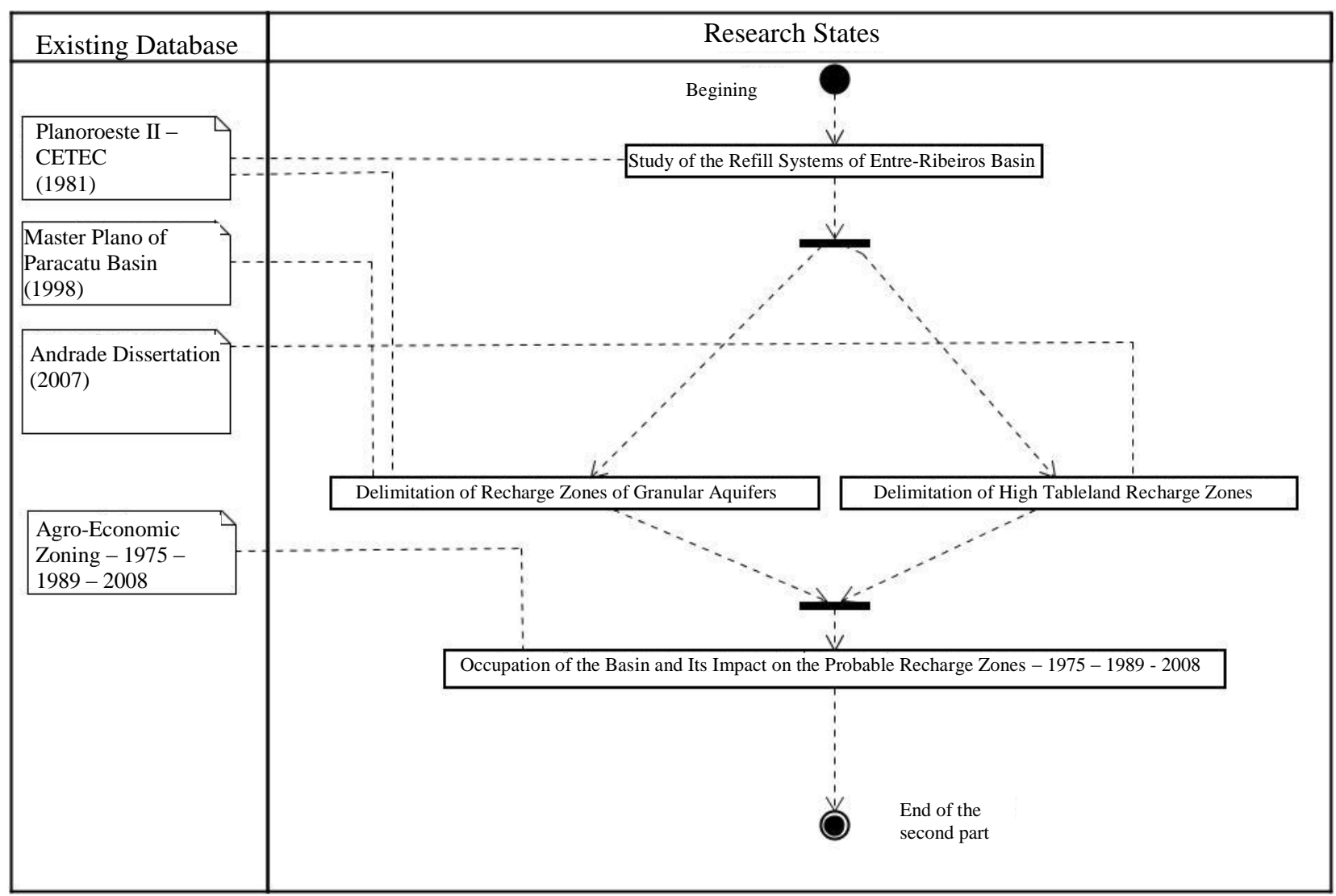

FIGURE 3. Activity diagram of the methodological steps of this paper.

\section{RESULTS AND DISCUSSION}

\section{Hydrogeology and aquifer recharge of Entre-Ribeiros Basin}

The result of the delimitation of probable recharge zone (concept of MARTINS JR. et al., 2006) can be seen in Figure 4. It should be noted that the study of identification and delimitation of these areas was based on previous studies, secondary data, cartographic analysis and GIS techniques.

To move from the concept of "probable recharge zone" to "precise recharge zone" (MARTINS JR. et al., 2006), it would required more detailed hydrogeological studies, with greater abundance of primary data from studies of drilling wells, tracer and chemical analyzes of surface and groundwater (ARRAES, 2008). These data need to be conjugated to more detailed studies of structural geology, potential piezometric lines, identification of hydrogeochemical faces of surface and groundwater water as well as hydro-climatic swings. Such studies could better identify and quantify the flow of groundwater. 


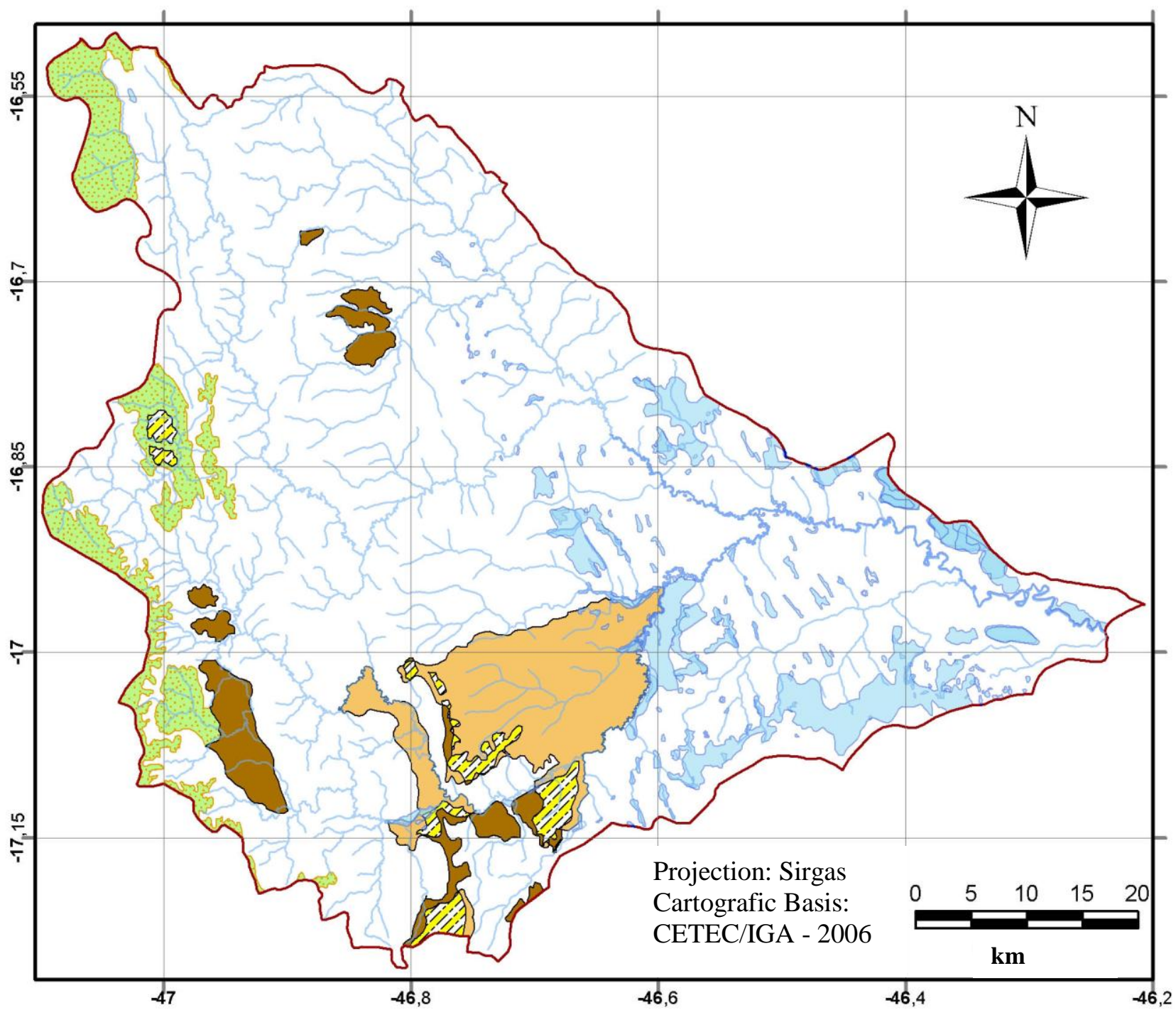

Probable main aquifer recharge zone

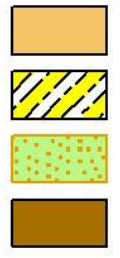

TQd Sandstone

Tabular TQd Sandstone

High tabular zone - above $900 \mathrm{~m}$

Hydrography

Ponds and Wetlands, permanent or temporary, and hydromorphic soils

Intermediary tabular zone - between 600 and $700 \mathrm{~m}$

FIGURE 4. Probable main aquifer recharge zones of Entre-Ribeiros Basin.

The fact of the marked areas to focus on the Southwest of Entre-Ribeiros further accentuates the importance of recharge, for climatological studies made by NUNES \& NASCIMENTO (2004) make evident that this is the region of highest rainfall of the Entre-Ribeiros Basin (Figure 5).

The difference between the rainfall stations in the municipalities of Paracatu (West Basin) and Unai (near the Northwest Basin) make evident a decrease of rainfall towards the North EntreRibeiros. The other rainfall stations in the Paracatu Basin indicate that there is also a decrease in rainfall as it heads for the eastern of Entre-Ribeiros Basin. Therefore, the Southwest of EntreRibeiros presents geological, geomorphological and climatological conditions to aquifers recharge. 


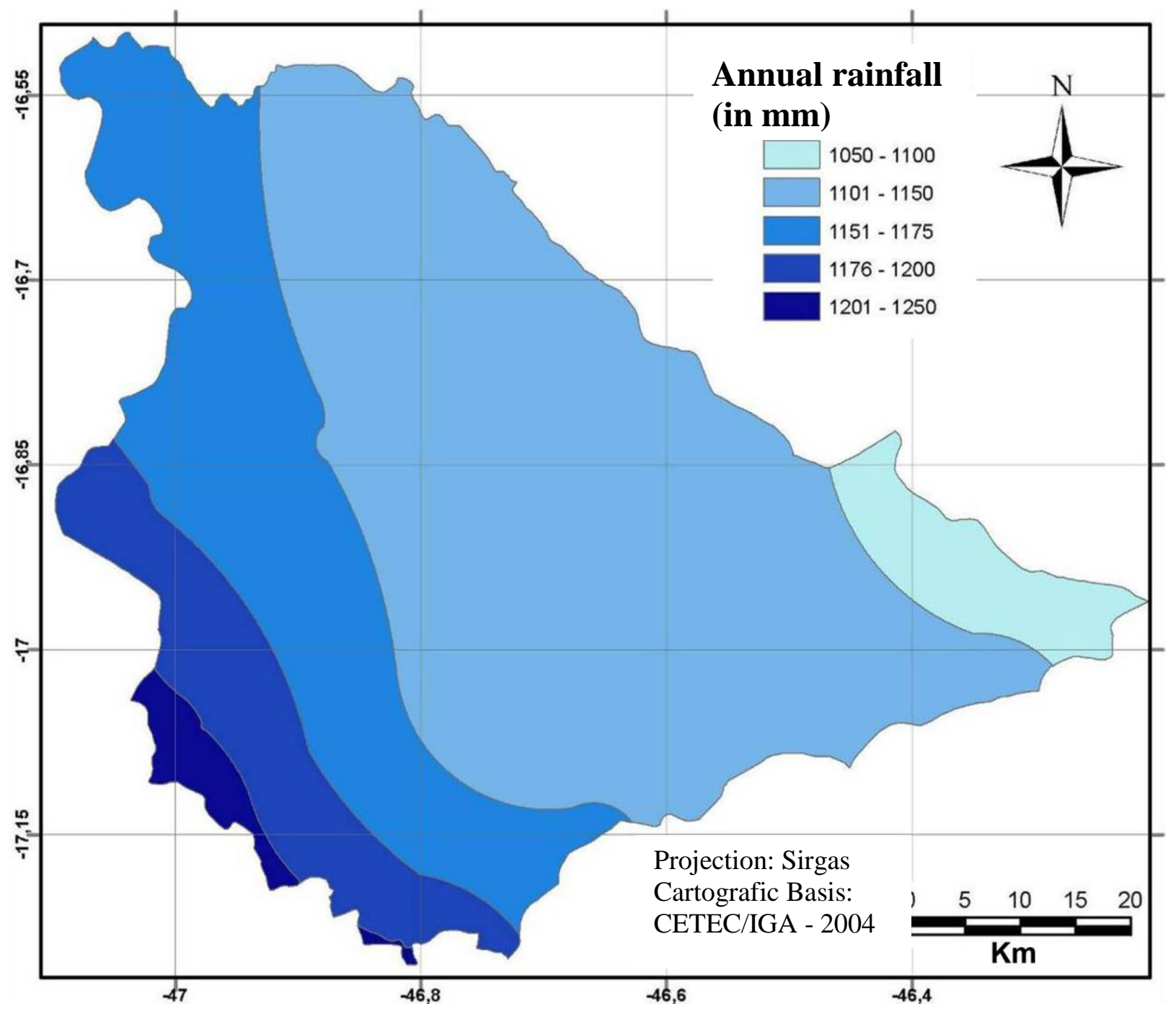

FIGURE 5. Annual rainfall map of Entre-Ribeiros Basin. Primary data obtained from NUNES and NASCIMENTO (2004).

\section{Changes in land use in the aquifers areas of recharge}

One impact of occupation and land degradation that affects water resources is soil compaction, combined with the fact of already having fewer obstacles to hinder the flow of water directly towards the watercourses than in a natural ecosystem - which causes decrease of the infiltration of water into the aquifer water reserves. Soil compaction will greatly depend on the proper techniques of agricultural management, and their influence on soil structure.

In Pedology, the structure may be defined as the arrangement between the primary skeletal grains (clay, silt and sand), the inter-granular plasma and the pore spaces, involving shape, size and arrangement of larger aggregated units - the peds (RESENDE et al., 2007; FERREIRA \& DIAS JR., 2002).

In preserved soils, the structure is largely responsible for the porosity and permeability of the soil (FERREIRA \& DIAS JR., 2002). However, agricultural methods that turn the soil over, such as plowing, cause obvious impacts on the physical properties. The impact on the structure is even greater when the soil is in situations of high humidity (after rain, irrigation or in hydromorphic land) or even in severe drought (FERREIRA \& DIAS JR., 2002). In such cases, soil compaction by mechanized agriculture has a greater potential impact on water infiltration, depending on the care management (TOMASINI et al., 2010). In addition, compaction of the soil surface layer is also caused by the force of rain drops impacting on the unprotected ground (Figure 6). 
However, techniques of soil conservation such as tillage have results that combine better the agricultural production with maintaining the quality of the soil, including those related to water circulation (SAMPAIO et al., 2010). In the case of cattle, the excess of frequency and density of grazing increases the compaction of the soil at a depth $0-5 \mathrm{~cm}$, reducing the infiltration of water (BRAGAGNOLO et al., 2007).

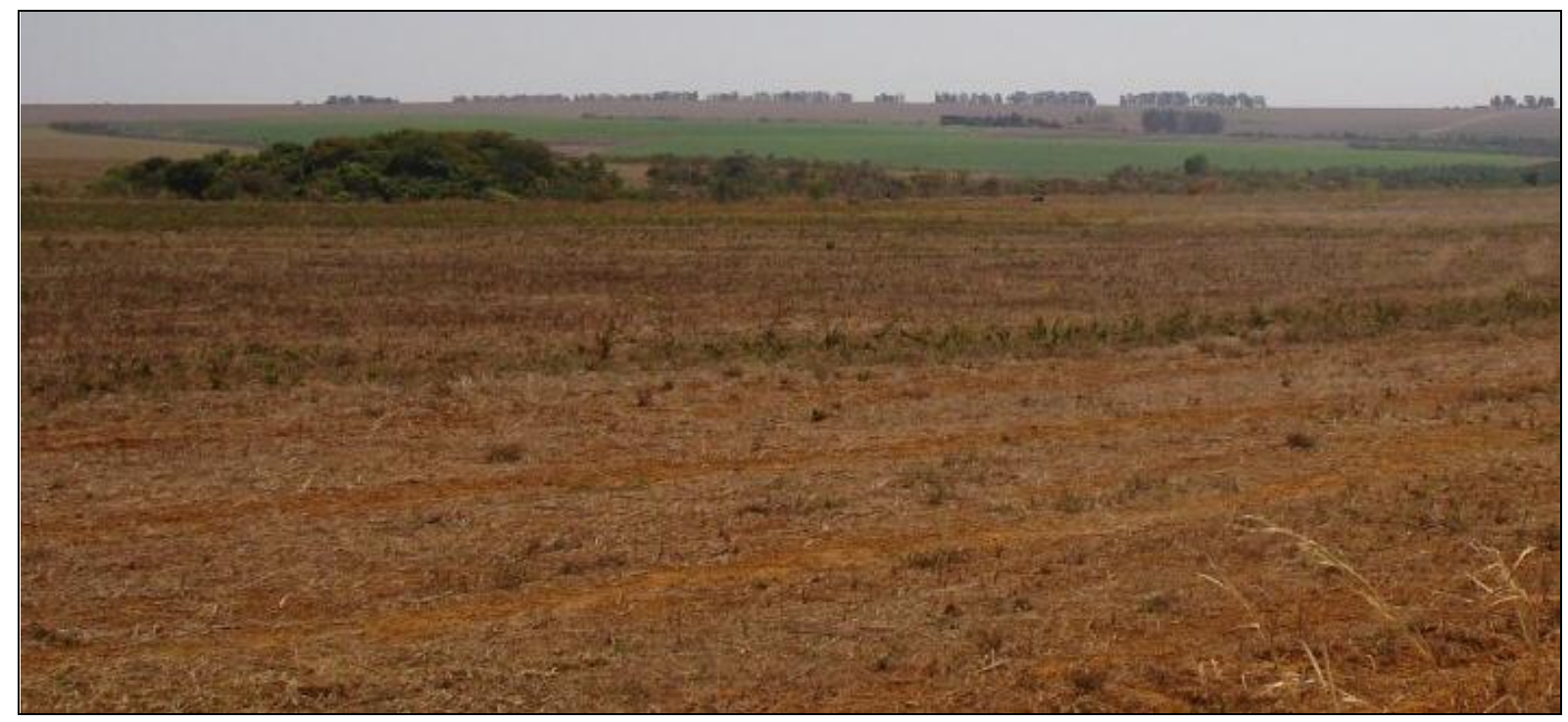

FIGURE 6. Example of intensive land use for agriculture, boosted by environmental attributes, on an aquifer probable recharge zone on high tabular zones on the west of Entre-Ribeiros Basin. 4703'14”S 1649'58'W (ANDRADE, 2007).

Therefore, the use of agricultural land in Entre-Ribeiros with the husbandry shows significant impact on the hydrogeological cycle. This impact is much greater if these land uses occur in areas of high aquifer recharge. However, soil management within its friable zone, using methods less harmful to the structure (such as tillage), and avoiding the exposure of bare soil during the rainy season, may significantly reduce compaction.

Table 1 shows the variations of each type of land in the Entre-Ribeiros Basin, while Table 2 shows data for bounded probable recharge zones. In general, the results and occupation trends in the recharge zones follow the standards of the rest of the basin. However, the occupation of native areas (mostly Cerrado) was more intense in areas of recharge, especially in the period 1989 to 2008.

TABLE 1. Area, percentage and temporal change of land use in Entre-Ribeiros Basin.

\begin{tabular}{|c|c|c|c|c|c|c|c|c|c|}
\hline \multirow{2}{*}{ Classes } & \multicolumn{2}{|c|}{1975} & \multirow{2}{*}{$\begin{array}{c}\text { Variation } \\
1975-1989 \\
(\%)\end{array}$} & \multicolumn{2}{|c|}{1989} & \multirow{2}{*}{$\begin{array}{c}\text { Variation } \\
\text { 1989-2008 } \\
(\%)\end{array}$} & \multicolumn{2}{|c|}{2008} & \multirow{2}{*}{$\begin{array}{c}\text { Variation } \\
1975-2008 \\
(\%)\end{array}$} \\
\hline & Hectare & $\%$ & & Hectare & $\%$ & & Hectare & $\%$ & \\
\hline $\begin{array}{l}\text { Agriculture } \\
\text { Traditional } \\
\text { Agriculture }\end{array}$ & 3287.91 & 0.83 & +1189.18 & 42387.22 & 10.70 & +135.47 & 99808.69 & 25.20 & +2935.63 \\
\hline Irrigated & 0.00 & 0.00 & - & 14743.63 & 3.72 & +165.41 & 39131.38 & 9.88 & - \\
\hline Husbandry & 58564.34 & 14.78 & +83.01 & 107181.11 & 27.06 & +7.72 & 115452.98 & 29.14 & +97.14 \\
\hline Settlements & 0.00 & 0.00 & - & 0.00 & 0.00 & - & 11426.19 & 2.88 & - \\
\hline Reforestation & 0.00 & 0.00 & - & 0.00 & 0.00 & - & 1230.89 & 0.31 & - \\
\hline Wetland & 6011.93 & 1.52 & -69.12 & 1856.74 & 0.47 & -61.79 & 709.38 & 0.18 & -88.20 \\
\hline Cerrado & 285968.28 & 72.19 & -32.23 & 193797.94 & 48.92 & -55.72 & 85821.77 & 21.66 & -69.99 \\
\hline Jungle & 42300.10 & 10.68 & -14.50 & 36168.39 & 9.13 & +17.66 & 42555.09 & 10.74 & +0.60 \\
\hline $\begin{array}{l}\text { Sub-Total } \\
\text { Anthropic } \\
\end{array}$ & 61852.25 & 15.61 & +165.65 & 164311.96 & 41.48 & +62.53 & 267050.13 & 67.41 & +331.75 \\
\hline Native Sub-Total & 334280.32 & 84.39 & -30.65 & 231823.07 & 58.52 & -44.32 & 129086.24 & 32.59 & -61.38 \\
\hline Total & 396132.57 & 100.00 & & 396135.03 & 100.00 & & 396136.36 & 100.00 & \\
\hline
\end{tabular}


TABLE 2. Area, percentage and temporal change of land use at the aquifer probable recharge zones in Entre-Ribeiros Basin.

\begin{tabular}{|c|c|c|c|c|c|c|c|c|c|}
\hline \multirow[b]{2}{*}{ Classes } & \multicolumn{2}{|c|}{1975} & \multirow{2}{*}{$\begin{array}{c}\text { Variation } \\
1975- \\
1989(\%)\end{array}$} & \multicolumn{2}{|c|}{1989} & \multirow{2}{*}{$\begin{array}{c}\text { Variation } \\
1989-2008 \\
(\%)\end{array}$} & \multicolumn{2}{|c|}{2008} & \multirow{2}{*}{$\begin{array}{c}\text { Variation } \\
1975-2008 \\
(\%)\end{array}$} \\
\hline & Hectare & $\%$ & & Hectare & $\%$ & & Hectare & $\%$ & \\
\hline Traditional & 277.25 & 0.44 & +1244.57 & 3727.76 & 5.97 & +108.26 & 7763.27 & 12.43 & \\
\hline Agriculture & & & & & & & & & \\
\hline Irrigated & & & - & & & & & & +2700.14 \\
\hline Agriculture & 0.00 & 0.00 & & 256.51 & 0.41 & +2150.62 & 5773.15 & 9.25 & +242.31 \\
\hline Husbandry & 7274.44 & 11.65 & +112.95 & 15491.11 & 24.81 & +60.75 & 24901.27 & 39.88 & \\
\hline Settlements & 0.00 & 0.00 & - & 0.00 & 0.00 & - & 9674.50 & 15.49 & - \\
\hline Reforestation & 0.00 & 0.00 & - & 0.00 & 0.00 & - & 0.00 & 0.00 & - \\
\hline Wetland & 124.99 & 0.20 & 0.00 & 124.99 & 0.20 & 0.00 & 124.99 & 0.20 & 0.00 \\
\hline Cerrado & 48555.24 & 77.76 & -21.15 & 38287.76 & 61.31 & -75.60 & 9341.92 & 14.96 & -80.76 \\
\hline Jungle & 6212.83 & 9.95 & -26.65 & 4557.05 & 7.30 & +6.78 & 4866.17 & 7.79 & -21.68 \\
\hline $\begin{array}{l}\text { Sub-Total } \\
\text { Anthropic }\end{array}$ & 7551.69 & 12.09 & +157.89 & 19475.38 & 31.19 & +147.04 & 48112.19 & 77.05 & +537.10 \\
\hline Native Sub-Total & 54893.06 & 87.91 & -21.72 & 42969.79 & 68.81 & -66.64 & 14333.08 & 22.95 & -73.89 \\
\hline Total & 62444.75 & 100.00 & & 62445.17 & 100.00 & & 62445.27 & 100.00 & \\
\hline
\end{tabular}

In the process of recent occupation of the probable recharge zones of the Entre-Ribeiros Basin, it was highlighted the significant presence of agrarian reform settlements (15.49\%). Practically the entire area of the settlements implemented in the basin overlaps areas of probable recharge.

Comparing the statistical data with the mappings occupation of land use, as well as geomorphological mapping (ANDRADE, 2007), it was revealed that the recharge areas corresponding to porous sandstone sediment mass of the Tertiary-Quaternary with a wavy to soft relief were preferentially occupied by settlements and husbandry, which is also quite significant in focused areas $(39.88 \%$, in 2008).

These data also support the observation that the agricultural cultivation in the eastern half of the basin shifted to husbandry activities for the western half, where there are major areas of recharge. Completing the scenario, at the ends of the Northwest Basin calls attention to significant expansion in areas of traditional and irrigated agriculture.

\section{CONCLUSIONS}

A central aspect of this study is the examination of surface water systems in relation to the lithostratigraphy, rock types, areas of exudation and relief, in order to characterize the probable recharge zones. This type of analysis is presented as promising and inexpensive to elucidate this question in a regionally efficient way with use of secondary data.

The process of land occupation was confronted with existing knowledge about the underground and surface water, based on Hydrogeology existing research. It was intended to establish relations between the agro-economic systems in the basin and the hydrological cycle as a whole. This approach provides the basis for integrated management of water resources within the ecological-economic perspective, focusing primarily in (1) the consumptive use of water, (2) the reduction of water infiltration into the soil by occupation of recharge zones and (3) the impact of footpath drainage, lagoons and floodplains.

It was concluded, therefore, that research on aquifer recharge helps to understand how the land use and the changes in the hydrological and hydrogeological cycle are integrated.

The usage model and identification of probable recharge zone considered here may be used systematically in other basins, as a procedure included in the preparation of master plans. It presents even as a starting point for evaluating the need for further studies in other critical areas with specific methods. In this respect, studies on the superficial flowage and percolation in each type of 
vegetation cover, land use (especially for different agricultural management), in conjunction with soil types and slope, would be important to scrutinize the hydrogeological impact caused by the advance of occupancy over native ecosystems.

\section{REFERENCES}

ANDRADE, L.M.G. Uso optimal do território de bacia hidrográfica com fundamentos no conceito de Geociências Agrárias e Ambientais: bacia do Ribeirão de Entre-Ribeiros no Vale do Rio Paracatu. 203 f. 2007. Dissertação (Mestrado) Universidade Federal de Ouro Preto, Ouro Preto, 2007.

ARRAES, T. M. Proposição de critérios e métodos para delimitação de Bacias Hidrogeológicas. 2008. 125f. Dissertação (Mestrado) - Instituto de Geociências, Universidade de Brasília, Brasília, 2008.

ASSAD, E.D.; SANO, E.E.; MOREIRA, L.; VALENTE, B.C. Caracterização de áreas nativas através do sensoriamento remoto e do sistema de informações geográficas: caso dos projetos de irrigação Entre-Ribeiros, Paracatu-MG. Planaltina: Centro de Pesquisa Agropecuária dos Cerrados, 1992, 23 p.

BRAGAGNOLO, J.; LANZANOVA, M.E.; LOVATO, T.; ELTZ, F.L.F.; GIRARDELO, V.C. Compactação do solo induzida por pisoteio bovino em sistemas de integração lavoura-pecuária sob plantio direto. CONGRESSO BRASILEIRO DE CIÊNCIA DO SOLO, 31., 2007, Gramado, Anais...

CETEC. FUNDAÇÃO CENTRO TECNOLÓGICO DE MINAS GERAIS. II plano de desenvolvimento integrado do noroeste mineiro: recursos naturais. Belo Horizonte, 1981.

CETEC. FUNDAÇÃO CENTRO TECNOLÓGICO DE MINAS GERAIS. Mapeamento, inventário e monitoramento da cobertura vegetal nativa e de florestas plantadas em parte do Estado de Minas Gerais. Belo Horizonte, 1989.

FERREIRA, M. M.; DIAS JR., M.S. Aspectos físicos do solo e o meio ambiente. Lavras: Universidade Federal de Lavras, 2002, 115 p.

FERREIRA NETO, J.A. (Coord.). Diagnóstico socioeconômico e ambiental e projeto final de assentamento do Projeto de Assentamento Belo Vale. Viçosa: UFV, 2006.

IGAM. INSTITUTO MINEIRO DE GESTÃO DAS ÁGUAS. Plano diretor de recursos hídricos do Rio Paracatu: resumo executivo. Governo de Minas Gerais. Comitê da Sub-Bacia Hidrográfica do Rio Paracatu. Belo Horizonte: Instituto Mineiro de Gestão das Águas, 2006. 384 p.

LATUF, M.O. Mudanças de uso do solo e comportamento hidrológico nas Bacias do Rio Preto e de Entre-Ribeiros. 2007. 103 f. Dissertação (Mestrado) - Universidade Federal de Viçosa, Viçosa, 2007.

LATUF, M.O.; MARTINEZ, M.A.; PRUSKI, F.F.; SILVA, D.D. Mudanças no uso do solo nas bacias do rio Preto e ribeirão Entre Ribeiros - MG a partir de imagens do sensor Landsat 5 TM. SIMPÓSIO BRASILEIRO DE SENSORIAMENTO REMOTO, 13., 2007. Florianópolis. Anais... p. 5.855-5.862.

MARTINS JR., P.P. Projeto GZRP - Gestão de zonas de recarga de Aqüíferos partilhadas entre as Bacias de Paracatu, São Marcos e Alto Paranaíba. Belo Horizonte: CETEC/FAPEMIG, 2009.

MARTINS JR., P.P.; CARNEIRO, J.A.; FERREIRA, E.N.; ENDO, I.; FERREIRA, O.C.; SIQUEIRA NETO, J.L; MARQUES, F.S.M.; FERNANDES, M.M.; ANDRADE, L.M.G.; NOVAES., L.A.d'A.; VASCONCELOS, V.V.; TOLENTINO, J.A.; PEREIRA, M.A.S.; ANTUNES, A.J.; DINIZ, C.P.L.; CARVALHO, F. Conservação de recurso hídrico no âmbito da gestão ambiental e agrícola de Bacia Hidrográfica. Belo Horizonte e Ouro Preto: CETEC, 2006, T.1-3. 
MARTINS JR., P.P.; ENDO, I.; VASCONCELOS, V.V.; NOVAES. L.A. d'A.; SEQUETTO, M.A. Modelo de integração de conhecimentos geológicos para auxílio à decisão sobre uso da terra em zonas de recarga de aqüífero. Revista Brasileira de Geociências, São Paulo, v.36, n.4, p.12-17, 2006.

MARTINS JR., P.P.; MEYER, S.T.; CARNEIRO, J.A.; DINIZ, C.P.L.; OLIVEIRA, P.H.B.; ABREU, J.C.; PEREIRA, J.S.; PAIVA, D.A. Arquitetura de conhecimentos em ecologia-economia para gestão ambiental de Bacia Hidrográfica. Belo Horizonte e Ouro Preto: CETEC, 2006. 103 p.

MOURÃO, M.A.A. Caracterização hidrogeológica da microrregião de Unaí. Projeto São Francisco. Província Mineral Bambuí - MG. CPRM. Brasília: Ministério das Minas e Energia, $2001.86 \mathrm{p}$.

MULHOLLAND, D.S. Geoquímica aplicada à avaliação de qualidade de sistemas aquáticos da Bacia do Rio Paracatu - MG. 2009. 95 f. Dissertação (Mestrado) - Universidade de Brasília, Brasília - DF, 2009.

NUNES, H.T.; NASCIMENTO, O.B. Base de dados meteorológicos. Belo Horizonte: Nota Técnica NT-CRHA 17/2004. In: MARTINS JR. (Coord.). Projeto CRHA. Memória Técnica da Fundação CETEC, 2004. 40 p. Disponível em: <www.cetec.br/crha〉.

PRUSKI, F.F.; RODRIGUEZ, R.D.G.; NOVAES, L.F. de; SILVA , D.D. da; RAMOS, M.M.; TEIXEIRA, A. de F. Impacto das vazões demandadas pela irrigação e pelos abastecimentos animal e humano, na Bacia do Paracatu. Revista Brasileira de Engenharia Agrícola e Ambiental, Campina Grande, v.11, n.2, p.199-210, 2007.

RAMOS, M.L.S.; PAIXÃO, M.M.O.M. Disponibilidade hídrica de águas subterrâneas produtividade de poços e reservas explotáveis dos principais sistemas aqüíferos. In: Plano Diretor de Recursos Hídricos da Bacia do Rio São Francisco. 2004, 41 p.

RESENDE, M.; CURI, N.; REZENDE, S. B.; CORRÊA, G. F. Pedologia: base para distinção de ambientes. 5.ed. Viçosa: NEPUT, 2007. 338 p.

RODRIGUEZ, R.G. Proposta conceitual para a regionalização de vazões. 2008. Tese (Doutorado) Universidade Federal de Viçosa, Viçosa, 2008.

RODRIGUEZ, R.G.; PRUSKI, F.F.; NOVAES, L.F.; RAMOS, M.M.; SILVA, D.D.; TEIXEIRA, A.F. Estimativa da demanda de água nas áreas irrigadas da Bacia do Rio Paracatu. Engenharia Agrícola, Jaboticabal, v.27, n.1, p.172-179, 2007.

RURALMINAS. Plano diretor de recursos hídricos da Bacia do Rio Paracatu - Planpar. Consórcio MAGNA / DAM / EYSER - Governo de Federal, Governo do Estado de Minas Gerais, Governo do Distrito Federal, Brasil, Fevereiro, R3. v.3, 1996.

SAMPAIO, F.M.T.; FERREIRA, M.M.; OLIVEIRA, M.S.; ALMEIDA, A.C.; JOSÉ, M.R. Variabilidade espacial da umidade de um Latossolo Vermelho-Amarelo sob plantio direto. Engenharia Agrícola, Jaboticabal, v.30, n.5, out. 2010. Disponível em: http://www.scielo.br/scielo.php?script=sci_arttext\&pid=S010069162010000500008\&lng=pt\&nrm=iso. Acesso em: 3 jan 2011.

TOMASINI, B.A.; VITORINO, A.C.T.; GARBIATE, M.V.; SOUZA, C.M.A.; SOBRINHO, T.A. Infiltração de água no solo em áreas cultivadas com cana-de-açúcar sob diferentes sistemas de colheita e modelos de ajustes de equações de infiltração. Engenharia Agrícola, Jaboticabal, v.30, n.6, dez. 2010. Disponível em http://www.scielo.br/scielo.php?script=sci_arttext\&pid=S010069162010000600007\&lng=pt\&nrm=iso. Acesso em: jan. 2011.

VASCONCELOS, V.V. Frentes agrícolas de irrigação e zoneamento ecológico-econômico: estudo de caso da bacia de Entre-Ribeiros - Noroeste de Minas Gerais. 2010. 142 f. Dissertação (Mestrado Tratamento da Informação Espacial) - PUC-Minas, Belo Horizonte, 2010. 
VASCONCELOS, V.V. Impactos e custos econômico-ambientais da agricultura moderna: estudo de caso da frente agrícola do noroeste de Minas Gerais. Monografia (Especialização em Solos e Meio Ambiente) - Universidade Federal de Lavras, Lavras, 2009. 83 p.

VASCONCELOS, V.V.; SOARES, J.; HADAD, R.M.;MARTINS JR., P.P.; CASTRO, J.F.M. História, economia e recursos naturais: a bacia hidrográfica de Entre-Ribeiros, no Noroeste de Minas Gerais. Caderno de Geografia, Belo Horizonte, v.18, p.39-57, 2008. 